\title{
Characterization of Bacterial Strains and their Resistance Status in Hospital Environment
}

\author{
Meriem EL Bakkali',2, Khadija Hmid ${ }^{3}$, Khalid EI Kari², Mimoune Zouhdi ${ }^{3}$, Mohammed EL Mzibri and Amin Laglaoui ${ }^{*}$ \\ ${ }^{1}$ Equipe de Recherche Biotechnologies et Génie des Biomolécules (ERBGB) FST- Tanger, Morocco \\ ${ }^{2}$ Unité de Biologie et Recherche Médicale, CNESTEN-Rabat, Morroco \\ ${ }^{3}$ Service de Microbiologie de l'Hôpital Ibn Sina de Rabat, Morroco
}

\begin{abstract}
Drug resistant Gram-negative or positive germs are associated with increased morbidity and mortality. Little is known about the epidemiology of this group of pathogens in Moroccan hospitals. During 1-year period, contamination controls of the surfaces and hands, in Ibn Sina hospital services, were performed from 10/2009 to 06/2010. A total of 470 surface and 135 hands samples were collected in the hospital and antibacterial resistance was examined. This study highlighted the presence of Staphyloccocus aureus, Pseudomonas sp, Klebsiella sp, which were widely disseminated in the inanimate surfaces and on the hands of health professionals and patients. An increased number of antimicrobial resistant isolates showed a reduced susceptibility to third cephalosporin's generation, quinolones and aminoglycosides. In Moroccan hospital, it is recommended to optimize antimicrobial drug use and to evaluate the microbiologic quality of environment, which it is most likely to be colonized with resistant bacteria
\end{abstract}

Keywords: Bacteria; CHU in Morocco; Hospital environment; Drug resistance

\section{Introduction}

Worldwide, the control of the hospital environment is a key of success of health care quality [1]. However, the increasing emergence and spread of pathogenic bacteria, without distinguishing between Gram-positive and Gram-negative organisms, in hospitals is of great concern and continues to challenge infection prevention and hospital epidemiology practice $[2,3]$. Hospital environments are responsible of the dissemination of microorganisms for different distances and progressive contamination of various supports, including surfaces, hands [4-7], air and water [8], and constitute therefore a major source of infections. Environmental microorganisms like Legionella pneumophila, E. coli, Mycobacterium xenopi or acynobacter, were the principal causes of serious recent epidemic infections, by their easier access to sterile body sites. They were the origin of increased lengths of hospital stay, severe illness, death and increased care cost $[9,10]$. Pathogens were found in all hospital units but the interest was usually focused on intensive care and surgery units, especially due to the vulnerability of patients in these units $[11,12]$. Health care professionals have established rigorous isolation guidelines; which give current recommendations comprising an infection control plan of the general measures to prevent and limit pathogen dissemination. That may provide an effective way to standardize and increase reliability the criteria of application of infection control methods in hospitals $[13,14]$. During the last decades, a bleaker picture has emerged with the appearance of multi-drug resistant pathogens, especially resistant strains to new generations of antibiotics, raising concerns of a future epidemic of virtually untreatable infections $[9,15]$. Micro-organisms in the inanimate hospital environment are said to contribute only negligibly to endemic nosocomial infections $[16,17]$. However, it is still difficult to document the relationship between the contamination of the hospital environment and nosocomial infections, given the difficulty of capturing such data and the limited studies made in this way, with the exception of some studies covering some co-morbidities, associated to Legionella sp, Aspergillus sp, atypical Mycobacteria or Staphylococci, including methicillin-resistant Staphylococcus aureus (MRSA) and vancomycin resistant Enterobaciteria (VRE) [3,18]. Even more, nosocomial infections is the second most common cause of death after cancer diseases, with around 1.4 million newly infection cases and over 500000 deaths estimated to occur annually in the European Union [19]. In Morocco, as other developing countries, data is limited to the number of cases registered in some medical centers, like Ibn Sina hospital in Rabat, which highlighted the presence of pathogens in distinct areas of the hospital environment like Pseudomonas aeruginosa, Staphylococcus aureus, Klebsiella sp and various Gram-negative bacilli. Therefore, the present study is planned to evaluate the rate of pathogen bacteria in the environment of the university hospital Ibn Sina in Rabat and to characterise their resistance status for better management of the hospital environment quality.

\section{Materials and Methods}

\section{Patients}

A total of 139 patients admitted for hospitalisation at the Central university hospital Ibn Sina in Rabat in January 2010 were recruited. These patients were selected among patients developing nosocomial infections occurring $48 \mathrm{hrs}$ post admission, according to the definitions described by the Centers for Disease Control [20]. The specimen sources included blood, urine, cerebrospinal fluid, pleural space, respiratory tract (collected during bronchoscopy or endotracheal suction), tip of central venous catheters, bedsores and surgical incision sites. All specimens were collected at the bed site, transferred to the laboratory immediately for microbiological analysis and were inoculated on proper culture media within two hours.

*Corresponding author: Amin Laglaoui, Équipe de Recherche en Biotechnologies \& Génie des Biomolécules, Faculté des Sciences et Techniques de Tanger, B.P. 416-Tanger-Maroc, Morroco, Tel: +212 6612279 71; E-mail: laglaouiamin@ yahoo.fr

Received September 10, 2015; Accepted September 29, 2015; Published October 06,2015

Citation: Bakkali MEL, Hmid K, Kari KE, Zouhdi M, Mzibri MEL, et al. (2015) Characterization of Bacterial Strains and their Resistance Status in Hospital Environment. J Trop Dis 4: 180. doi:10.4172/2329-891X.1000180

Copyright: (c) 2015 Bakkali MEL, et al.This is an open-access article distributed under the terms of the Creative Commons Attribution License, which permits unrestricted use, distribution, and reproduction in any medium, provided the original author and source are credited. 


\section{Environmental sampling}

Sampling was performed on hands of hospital personnel and admitted patients before disinfection. Environmental sampling was performed during the morning after the regular daily cleaning. The date, time, conditions and sites of sampling were noted. Different surfaces and locations were included (Bed covers, bed rails, masks, oxygen bubbler, carriage of care, laboratory bench, bedside table, surgical operation table, breathing tubes, infusion pump, aspirators, baby incubators, wash-hand basins, water taps, shower fitting, door handles, floors and others). Basically, 20 swabs were used, at least, for each sampling site, giving a total of 470 samples. For sampling, sterile polyester fibre-tipped applicator swabs (Becton Dickinson, Basel, Switzerland) were moistened in $2 \mathrm{ml}$ sterile saline solution and rolled several times over a surface area of around $25 \mathrm{~cm}^{2}$.

\section{Bacteriological testing}

Spits were inoculated onto the Chocolate enriched or bacitracin agar in $5 \% \mathrm{CO}_{2}$, and for Neisseria sp, the $5 \%$ sheep blood agar was used. Blood was injected into two or more "blood bottles" with specific media for aerobic and anaerobic organisms and sub cultured onto 5\% sheep blood agar for Streptococcus pneumoniae, Chapman agar plates for Gram-positive staphylococcus, DCL Desoxycholate citrate lactose agar plates for Gram-negative bacteria and chocolate agar for exigent bacteria. Cerebrospinal fluid was inoculated onto Chocolate enriched / bacitracin agar in $5 \% \mathrm{CO}_{2}$. The urine specimens were inoculated onto phosphate buffered saline agar, Cystine Lactose Electrolyte Deficient agar and Mac Conkey agar. The other Clinical specimens were inoculated onto DCL agar, 5\% sheep blood agar, Selenite broth for Salmonella species, Chocolate enriched / bacitracin agar in $5 \% \mathrm{CO}_{2}$ for Neisseria sp and Haemophilus sp. Swabs were vortexed and subcultured on Chapman agar plates for Gram-positive bacteria, DCL Desoxycholate citrate lactose agar plates for Gram-negative bacteria and chocolate agar for exigent bacteria. The plates were incubated for 18-24 $\mathrm{h}$ at $37^{\circ} \mathrm{C}$ and visible colonies were further sub-cultured and incubated for $24 \mathrm{~h}$ at $37^{\circ} \mathrm{C}$. Isolation and identification of microorganisms were done according to standard procedures. Bacteria were identified by examination of colonial morphology, haemolytic characteristics on appropriate agar media, Gram staining, rapid tests (catalase, oxidase, coagulase/Dnase, optochin disc, bile solubility, spot indole, latex agglutination), and classic and API galleries (BioMérieux, France) [21].

\section{Drug susceptibility testing}

Drug susceptibility testing was performed by the method of disk diffusion according to the guidelines of the National Committee for Clinical Laboratory Standards [22]. The culture of each isolate was diluted to have turbidity around $0.5 \mathrm{McFarland}$ standard, then plated onto Muller-Hinton agar plate (Difco, France). Antibiotic disks (Oxoid, France) were applied to each plate. After incubation at $35^{\circ} \mathrm{C}$ for $24 \mathrm{~h}$, the zone of inhibition diameter was measured. Data analyses were performed using the susceptibility cut points according to the Clinical and Laboratory Standards Institute guidelines [23]. Multiresistance of Gram-negative bacteria was defined as resistance to at least three antibiotics of the following antibiotic classes: penicillins, third-generation cephalosporins, carbapenems, quinolones and aminoglycosides.

\section{Statistical Analysis}

Statistical analysis was performed using SPSS 17.1 software that uses directly the Yates' chi-square test for small sample size. Differences were considered statistically significant for $\mathrm{P} \leq 0.05$.

\section{Results}

\section{Isolation of pathogen strains from patients, hospital surfaces and hands}

A total of 814 sampling were made, 139 from patients, 470 from surfaces and 205 from personnel and patients' hands. Personnel and patients' hands were the most infected samples. Indeed, $98.5 \%$ of samples from personnel and patients' hands were infected with pathogen bacteria $(202 / 205)$. Whereas only $46 \%$ of patients $(64 / 139)$ and $26.8 \%$ of surfaces' samples $(126 / 470)$ were positives. Among the 392 positive samples, 2182 pathogen strains were isolated, comprising 1112 Gram-positive and 1070 Gram-negative bacteria.

\section{The distribution of strains according to samples' origins}

The distribution of strains isolated from patients, surfaces and hands, and their detection rates was reported in Table 1 and showed that 67 bacteria were isolated from patients, 865 from surfaces of various locations in different services and 1250 from personnel and patients' hands. Characterisation of strains isolated from patients showed clearly a high prevalence of Gram-negative bacteria. Bacterial identification showed a predominance of Klebsiella sp (16,42\%), E. coli (16,42), Enterobacter sp (11.94\%) and Pseudomonas sp (10.45\%). Pathogen bacteria were also isolated from personnel hands Table 1. Globally, isolation of Gram-positive bacteria was higher than Gramnegative bacteria. Gram-positive bacteria were isolated from 130 of 202 (64.36\%) of hands, however Gram-negative bacteria were isolated only from $35.64 \%$ of hands (72/202). Moreover, no significant difference was obtained on sampling from personnel' and patients' hands either for Gram-negative or Gram-positive bacteria ( $\mathrm{p}=0.9656)$. The distribution of strains isolated and their detection rates on surfaces is also reported in Table 1. Results clearly demonstrate the presence of both Grampositive and Gram-negative bacteria with the predominance of Pseudomonas sp, Klebsiella sp, Staphylococcus aureus and coagulase negative Staphylococcus, Pseudomonas sp was isolated from $23.12 \%$ and $11.60 \%$ of surfaces and hands respectively. Klebsiella was collected from $16.76 \%$ of surfaces and $16 \%$ of total hands. Staphylococcus aureus represented $12.72 \%$ and $20.8 \%$ of total isolates from surfaces and hands respectively. Interestingly, coagulase negative Staphylococcus were the most predominant bacteria isolated from the hospital environment and represented $30.64 \%$ and $30.80 \%$ of total strains isolated from surfaces and personnel and patients' hands, respectively. Moreover, the percentages of detection of Gram-positive and Gram-negative isolated at different locations is summarised in Figure 1. For both Gram-negative and Gram-positive bacteria, the main infected surfaces were the bed covers and bathroom representing the major reservoirs of pathogens. Moreover, Gram-negative bacteria were predominant in wash-hand basins and the patient's masks whereas Gram-positive bacteria prevail in samples taken from tables.

\section{Isolation and distribution of drug resistant strains}

The resistance status of isolated bacteria was also evaluated. Among the 2182 isolates, 322 were drug resistant strains. Significant difference of the distribution of theses strains was observed depending on the origin of sampling $(\mathrm{p}<0.0001)$. Indeed, 37 strains of 67 isolates from patients were drug resistant giving the highest rate of multi drug resistance (55.22\%). However, only $15.51 \%$ (150/865) and $9.53 \%$ $(135 / 1250)$ strains isolated from surfaces and hands were drug resistant respectively. Table 2 illustrates the rate of multi-drug resistance of isolated strains. Drug resistant rate ranged mainly from 7.69 to $66.67 \%$. However, all strains belonged to providencia genus and only $0.31 \%$ of 
Citation: Bakkali MEL, Hmid K, Kari KE, Zouhdi M, Mzibri MEL, et al. (2015) Characterization of Bacterial Strains and their Resistance Status in Hospital Environment. J Trop Dis 4: 180. doi:10.4172/2329-891X.1000180

Page 3 of 6

\begin{tabular}{|c|c|c|c|c|c|c|c|}
\hline & Strains & Patients & $\%$ & Surfaces & $\%$ & Hands & $\%$ \\
\hline \multirow{10}{*}{ Gram-negative bacteria } & Pseudomonas sp & 7 & 10,45 & 200 & 23.12 & 145 & 11.60 \\
\hline & Klebsiella sp & 11 & 16,42 & 145 & 16.76 & 200 & 16.00 \\
\hline & Enterobacter sp & 8 & 11,94 & 10 & 1.16 & 65 & 5.20 \\
\hline & E. coli & 11 & 16,42 & 60 & 6.94 & 70 & 5.60 \\
\hline & Proteus sp & - & - & 30 & 3.47 & 45 & 3.60 \\
\hline & Providencia sp & 1 & 1,49 & 5 & 0.58 & 0 & 0 \\
\hline & Acinétobacter sp & 5 & 7,46 & 20 & 2.31 & 10 & 0.80 \\
\hline & Citrobacter sp & 3 & 4,48 & 5 & 0.58 & 5 & 0.40 \\
\hline & Morganella sp & 3 & 4,48 & - & - & - & - \\
\hline & Sub-total & 55 & 82,09 & 475 & 54.91 & 540 & 43.20 \\
\hline \multirow{4}{*}{ Gram-positive bacteria } & $\begin{array}{c}\text { Staphyloccocus } \\
\text { aureus }\end{array}$ & 3 & 4,48 & 110 & 12.72 & 260 & 20.80 \\
\hline & $\begin{array}{c}\text { coagulase negative } \\
\text { Staphylococcus }\end{array}$ & 5 & 7,46 & 265 & 30.64 & 385 & 30.80 \\
\hline & Streptoccocus sp & 4 & 5,97 & 15 & 1.73 & 65 & 5.20 \\
\hline & Sub-total & 12 & 17,91 & 390 & 45.09 & 710 & 56.80 \\
\hline Total & & 67 & & 865 & & 1250 & \\
\hline
\end{tabular}

Table 1: Distribution of pathogens isolated from hospital locations and personnel and patients' hands.

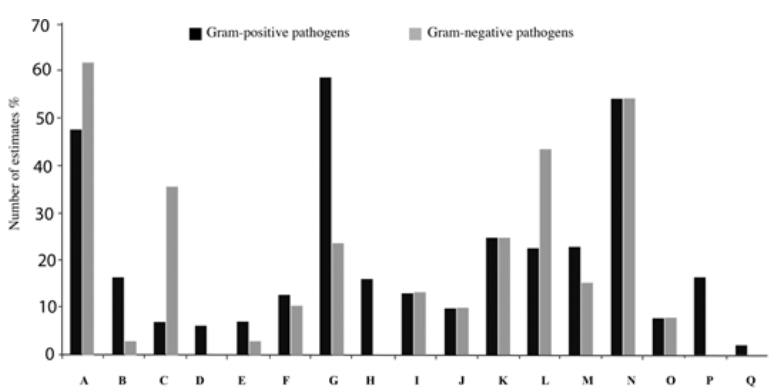

A: Bed covers; B: Bed rails; C: Masks; D: Oxygen bubbler; E: Carriage of case; F: Laboratory bench; G: Bedside table; H: Surgical operation table; I: Breathing tubes; J: Infusion pump; K: Babies incubators; L: Wash-hand bassins; M: Water taps; N: Shower fitting; O: Floors; p: Doors; Q: Others.

Figure 1: Detection of multi-resistant Gram-positive and Gram-negative bacteria on different environmental items.

\begin{tabular}{|c|c|c|c|c|}
\hline \multicolumn{2}{|c|}{ Isolated strains } & $\begin{array}{c}\text { Number } \\
\text { of } \\
\text { isolates }\end{array}$ & $\begin{array}{c}\text { Number of multi- } \\
\text { drug resistant } \\
\text { isolates }\end{array}$ & Percentage \\
\hline \multirow{10}{*}{$\begin{array}{c}\text { Gram- } \\
\text { negative } \\
\text { bacteria }\end{array}$} & Klebsiella sp & 356 & 86 & 24,16 \\
\hline & Pseudomonas sp & 352 & 86 & 24,43 \\
\hline & Enterobacter sp & 83 & 38 & 45,78 \\
\hline & Citrobacter sp & 13 & 1 & 7,69 \\
\hline & E. coli & 141 & 34 & 24,11 \\
\hline & Proteus sp & 81 & 12 & 14,81 \\
\hline & Acinétobacter sp & 35 & 9 & 25,71 \\
\hline & Providencia sp & 6 & 6 & 100,00 \\
\hline & Morganella sp & 3 & 2 & 66,67 \\
\hline & Sub-total & 1070 & 274 & 25,61 \\
\hline \multirow{4}{*}{$\begin{array}{l}\text { Gram- } \\
\text { positive } \\
\text { bacteria }\end{array}$} & $\begin{array}{c}\text { Staphyloccocus } \\
\text { aureus }\end{array}$ & 373 & 38 & 10,19 \\
\hline & $\begin{array}{c}\text { Coagulase } \\
\text { negative } \\
\text { Staphyloccocus }\end{array}$ & 655 & 2 & 0,31 \\
\hline & Streptococcus sp & 84 & 8 & 9,52 \\
\hline & Sub-total & 1112 & 48 & 4,32 \\
\hline \multicolumn{2}{|r|}{ Total } & 2182 & 322 & 14.76 \\
\hline
\end{tabular}

Table 2: Characterisation of multi-drug resistant strains. coagulase negative Staphylococcus were drug resistant. The distribution of drug resistant strains according to the origin of sampling is reported in Table 3. Drug resistant strains belonging to Citrobacter, Morganella and coagulase negative Staphylococcus were isolated only from patients whereas the other drug resistant strains were isolated from patients and from surfaces and/or hands.

\section{Drug resistance status}

The Tables 4 and 5 show the resistance profile of different drug resistant pathogens isolated from hospital during this study. The majority of gram-negative isolated strains were characterised by the high resistance to ampicillin and the association amoxicillin-clavulanic acid. Klebsiella sp and Pseudomonas sp showed high rates of resistance to $3^{\text {rd }}$ generation of cephalosporins. Indeed, resistance to ceftriaxone was observed in $90.70 \%$ of drug resistant Klebsiella strains whereas resistance to ceftazidime and cefotaxime was observed in all drug resistant Klebsiella strains. Furthermore, $71.43 \%, 100 \%$ and $93.51 \%$ of drug resistant Pseudomonas strains were resistant to ceftazidime, cefotaxime and ceftriaxone respectively. The 4 strains demonstrated a particularly high resistance to aminosids antibiotics, especially

\begin{tabular}{|c|c|c|c|c|}
\hline & Strains & Patients \% & Surfaces $\%$ & Hands $\%$ \\
\hline \multirow{10}{*}{$\begin{array}{c}\text { Gram-negative } \\
\text { bacteria }\end{array}$} & Pseudomonas sp & 16,21 & 30 & 25,93 \\
\hline & Klebsiella sp & 16,21 & 33,33 & 22,22 \\
\hline & Enterobacter sp & 8,11 & - & 25,93 \\
\hline & E. coli & 10,81 & 20 & - \\
\hline & Proteus sp & 5,41 & 6,67 & - \\
\hline & Providencia sp & 2,7 & 3,33 & - \\
\hline & Acinétobacter sp & 10,81 & - & 3,7 \\
\hline & Citrobacter sp & 2,7 & - & - \\
\hline & Morganella sp & 5,41 & - & - \\
\hline & Sub-total & 78,37 & 93,33 & 77,78 \\
\hline \multirow{4}{*}{$\begin{array}{c}\text { Gram-positive } \\
\text { bacteria }\end{array}$} & $\begin{array}{c}\text { Staphyloccocus } \\
\text { aureus }\end{array}$ & 8,11 & 6,67 & 18,52 \\
\hline & $\begin{array}{l}\text { coagulase negative } \\
\text { Staphylococcus }\end{array}$ & 5,41 & - & - \\
\hline & Streptoccocus sp & 8,11 & - & 3,7 \\
\hline & Sub-total & 21,63 & & 22,22 \\
\hline Total & & 100 & 100 & 100 \\
\hline
\end{tabular}

Table 3: Distribution of MDR strains isolated from patients, surfaces and hands. 


\begin{tabular}{|c|c|c|c|c|c|c|c|c|c|c|c|c|}
\hline \multirow{2}{*}{ Antibiotic } & \multicolumn{3}{|c|}{ Klebsiella sp } & \multicolumn{3}{|c|}{ Pseudomonas sp } & \multicolumn{3}{|c|}{ Enterobacter sp } & \multicolumn{3}{|c|}{ E. coli } \\
\hline & $\mathrm{N}$ & $\mathrm{R}$ & $\%$ & $\mathrm{~N}$ & $\mathrm{R}$ & $\%$ & $\mathrm{~N}$ & $\mathrm{R}$ & $\%$ & $\mathrm{~N}$ & $\mathrm{R}$ & $\%$ \\
\hline AMP & 86 & 86 & 100 & 82 & 82 & 100 & 38 & 38 & 100 & 27 & 27 & 100 \\
\hline AMC & 86 & 86 & 100 & 82 & 82 & 100 & 38 & 38 & 100 & 27 & 21 & 77.78 \\
\hline IMP & 73 & 5 & 6.85 & 77 & 26 & 33.77 & 38 & 0 & - & 27 & 0 & - \\
\hline ERT & 46 & 0 & - & 22 & 22 & 100 & 5 & 5 & 100 & 21 & 0 & - \\
\hline CRO & 86 & 78 & 90.70 & 77 & 72 & 93.51 & 38 & 23 & 60.53 & 22 & 16 & 72.73 \\
\hline CTX & 68 & 68 & 100 & 57 & 57 & 100 & 33 & 18 & 54.54 & 17 & 16 & 94.12 \\
\hline CTZ & 86 & 86 & 100 & 77 & 55 & 71.43 & 38 & 23 & 60.53 & 27 & 16 & 59.26 \\
\hline AK & 83 & 10 & 12.05 & 82 & 30 & 36.58 & 38 & 2 & 5.26 & 27 & 1 & 3.70 \\
\hline $\mathrm{CN}$ & 86 & 63 & 73.26 & 76 & 46 & 60.53 & 38 & 23 & 60.53 & 22 & 16 & 72.73 \\
\hline NET & 86 & 67 & 77.91 & 72 & 46 & 63.89 & 38 & 18 & 47.37 & 27 & 16 & 59.26 \\
\hline CIP & 86 & 63 & 73.26 & 72 & 42 & 58.33 & 38 & 18 & 47.37 & 27 & 21 & 77.78 \\
\hline OFX & 53 & 30 & 56.60 & 56 & 41 & 73.21 & 23 & 10 & 43.48 & 16 & 10 & 62.5 \\
\hline SXT & 80 & 65 & 81.25 & 82 & 62 & 75.61 & 30 & 20 & 66.67 & 26 & 21 & 80.77 \\
\hline
\end{tabular}

$\mathrm{N}$ : Number of tested strains; R: number of resistant strains to the tested antibiotic; \%: percentage of resistance; AMP: ampicillin; AMC: association of amoxicillin and calvulanic acid; IMP: imipenem; ERT: ertapenem; CRO: ceftriaxone; CTX: cefotaxime; CTZ: ceftazidime; AK: amikacin; CN: Gentamicin ; NET: nethilmycin; CIP: ciprofloxacin; OFX: ofloxacin; SXT: Sulfamethoxazole + trimethoprim.

Table 4: Characterisation of antibiotic resistance of isolated gram-negative drug resistant strains

\begin{tabular}{|c|c|c|c|}
\hline \multirow{2}{*}{ Antibiotic } & \multicolumn{3}{|c|}{ Staphylococcus aureus } \\
\cline { 2 - 4 } & $\mathrm{N}$ & $\mathrm{R}$ & $\%$ \\
\hline AMP & 36 & 15 & 41.67 \\
\hline AMC & 36 & 15 & 41.67 \\
\hline IMP & 30 & 10 & 33.33 \\
\hline CRO & 20 & 20 & 100 \\
\hline CTX & 15 & 15 & 100 \\
\hline CTZ & 25 & 20 & 80 \\
\hline AK & 36 & 1 & 2.78 \\
\hline CN & 31 & 11 & 35.48 \\
\hline NET & 36 & 1 & 2.78 \\
\hline CIP & 30 & 20 & 66.67 \\
\hline OFX & 25 & 20 & 80 \\
\hline SXT & 30 & 10 & 33.33 \\
\hline OX & 21 & 10 & 47.62 \\
\hline E & 36 & 20 & 55.55 \\
\hline AF & 31 & 5 & 16.13 \\
\hline VA & 36 & 0 & 0 \\
\hline Tay & & & \\
\hline
\end{tabular}

$\mathrm{N}$ : Number of tested strains; R: number of resistant strains to the tested antibiotic $\%$ : percentage of resistance; AMP: ampicillin; AMC: association of amoxicillin and calvulanic acid; IMP: imipenem; CRO: ceftriaxone; CTX: cefotaxime; CTZ: ceftazidime; AK: amikacin; CN: gentamicin; NET: nethilmycin; CIP: ciprofloxacin OFX: ofloxacin; SXT: Sulfamethoxazole+ trimethoprim; OX: oxacicllin; E: erythromycin; AF: fusidic acid; VA: vancomycin.

Table 5: Characterisation of antibiotic resistance of isolated gram-positive drug resistant strains.

gentamycin and nethilmycin, with a rate of resistance ranging from $47.37 \%$ to $76.14 \%$. However, low rates of resistance to amikacin were registered. Infact, $36.58 \%$ of Pseudomonas strains were resistant to amikacin, whereas only $12.05 \%, 5.26 \%$ and $3.70 \%$ of Klebsiella, Enterobacter and E. coli exhibited resistance to this aminoglycoside antibiotic. A relative high resistance to ciprofloxacin, ofloxacin and Sulfamethoxazole+ trimethoprim was observed for the 4 tested strains. Moreover, this study highlights the lowest frequency of resistance to imipenem. On the other hand, the gram-positive Staphylococcus aureus strain was characterised by the high resistance to the $3^{\text {rd }}$ generation of cefalosporins (80-100\%). Among the 3 tested aminoglycoside antibiotics, resistance to gentamycin was observed in $35.48 \%$ of drug resistant Staphylococcus aureus strains, whereas only $2.78 \%$ of strains exhibited resistance to the other aminoglycoside antibiotics; amikacin and nethilmycin. $S$. auresu strains showed a high resistance to quinolone drugs $(>66 \%)$, including ciprofloxacin and ofloxacin, low resistance to Sulfamethoxazole + trimethoprim and fusidic acid, whereas no strain exhibited resistance to vancomycin. Moreover, more than $47 \%$ of Staphylococcus aureus strains were MRSA as determined by the susceptibility testing to oxacillin.

\section{Discussion}

In this study, we have clearly demonstrated that microorganisms isolated from the hands of personnel or patients are much higher than those isolated from surfaces and patients. That ensures the possibility of disseminating microorganisms by professions who neglect to wash their hands after touching patients [24,25]. Several studies have reported the importance of frequent and adequate hand washing to reduce rates of Hospital-acquired infections [26-29], showed that hands regularly acquire bacterial pathogens, after contact with patients and the environmental surfaces near hospitalised patients [16]. Moreover, many pathogens responsible of nosocomial infections can survive on dry surfaces for several weeks [30]. Characterisation of pathogen strains showed the predominance of gram-negative bacteria from patients and surfaces and Gram-positive bacteria from hands. Previous studies have reported different rates of viable microorganisms on healthcare personnel hands, Acinetobacter sp. 3-15\%, Klebsiella sp. 17\%, MRSA up to $16.9 \%$, Pseudomonas sp. 1.3-25\% [31]. Gram-positive pathogens such as Staphylococci strains show much higher transmission rates compared to Gram-negatives. That could be explained by diminished survival time of Gram-negatives in the environment [32]. In fact, Gram-negative bacteria other than Acinetobacter sp [33], survive on dry surfaces for few hours only, while the survival time can be several days for Staphylococci $[34,35]$. In this study strains isolated from patients are basically the same as those isolated from surfaces of various hospital locations and hands, indicating the persistence of these strains in the hospital environment. However interestingly, investigations into epidemics have not confirmed that patients were infected specifically due to surrounding environmental contamination [2,36], but depend also on the patient health status. The main pathogens isolated are Staphylococcus aureus, coagulase negative Staphylococcus, Pseudomonas sp, Enterococci, Klebsiella sp, proteus sp and E. coli. It's widely accepted that these pathogens are the major cause of hospital-acquired infections. Indeed, gram-positive organisms including coagulase 
negative Staphylococcus, Staphylococcus aureus and Enterococci are responsible of nosocomial blood stream infections [37,38]. E. coli is a very common cause of nosocomial urinary tract infection. The other pathogens including Pseudomonas aeruginosa, Klebsiella sp, Proteus, Staphylococcus epidermidis and Enterococci are responsible for epidemic lower respiratory tract infection in many hospitals. Moreover, Klebsiella $s p$, Pseudomonas sp, Proteus sp, E. coli and Staphylococcus aureus are common cause of blood stream nosocomial infections in neonates [39]. Different studies have reported low bacterial counts of multi-resistant organisms in the environment of colonised patients $[2,40,41]$. This was confirmed by our findings reporting that only $15.51 \%$ of strains isolated from surfaces and $9.53 \%$ of strains isolated from hands were multidrug resistant, in contrast, $55.22 \%$ of strains isolated from patients were drug resistant. Our results clearly demonstrated that the rate of drug resistant Gram-negative bacteria was much higher than Gram-positive bacteria, from both patients and the hospital environment. Previous studies showed converse results with a high degree of Gram-positive drug resistant isolates from the hospital environment [2].

Basically, resistance profiles of strains colonised hospital environment were similar to those isolated from patients; this suggests that patients could be contaminated from hospital surfaces or through healthcare workers. In this field, strain typing using molecular approaches will be of a great interest to compare bacteria from patients and the hospital environment. Thus, the implementation and/or reinforcement of effective cleaning measures is necessary to limit the dissemination of pathogens in the hospital environment and to contaminate newly admitted patients [3,42-44]. Inappropriate use of antibiotics allows bacterial pathogens, or opportunistic strains (from non-clinical environments) to acquire new resistance mechanisms $[45,46]$. $\beta$-lactams are the most widely used antibiotics leading to the emergence of high number of resistant strains. Currently, the most used antibiotics in Morocco are $3^{\text {rd }}$ generation of cephalosporins, carbapenems, quinolones and aminoglycosides. Unfortunately, the excessive and not efficient use of theses antibiotics might be associated with increased risk of microbial resistance. In the current study, the frequency of resistance to the most used antimicrobial agents, including cephalosporins, was relatively higher. The frequency of resistance to the main antimicrobial agents was $60.53 \%$ to $100 \%$ for ceftriaxone, $59.26 \%$ to $100 \%$ for ceftazidime, $54.54 \%$ to $100 \%$ for cefotaxime, $47.37 \%$ to $77.78 \%$ for ciprofloxacin and $6.86 \%$ to $33.77 \%$ for imipenem. Overall, our results corroborate with other studies conducted in different countries. In previous studies conducted in Iran, Oman and Turkey, the resistance to ceftriaxone ranged from 68 to $98.1 \%$ [47-49]. Conversely, the resistance to ceftriaxone was much lower in Belgian as reported by Glupczynski et al. That could be due to adequate empirical treatment using this antibiotic [50]. In the current study, the mean resistance to ceftazidime was $79.1 \%$. It is almost similar to an Iranian study with resistance ranging from 60 to $88 \%[47,49]$. Once again, this resistance is higher than reported results for Belgian study [50]. In our study, resistance to cefotaxim ranged from $54.54 \%$ to $100 \%$, this in agreement with reported data from Turkey with percentage of resistance ranging between $59.4 \%$ and $96.2 \%$ [49]. During the last decades, susceptibility to quinolones has decreased more than other antibiotics worldwide, and this might be a consequence of the wide usage of these antibiotics. Quinolone-resistant strains might therefore spread more easily than the strains resistant to other antimicrobial agents [51]. The published data on the resistance of hospital bacterial strains to ciprofloxacin are controversial. Indeed, in an Iranian study resistance to ciprofloxacin was 56\% - 77\% [47], 20 to 59.2\% in Turkey [49]. However, it was much higher in Argentina exceeding $80 \%$ and is less than 25.5\%, in a Brazilian study $[52,53]$. In the present study, the mean resistance to imipenem is $16.73 \%(6.85 \%-33.77 \%)$.The frequency of resistance to imipenem was $14 \%$ in an Iranian study, $13 \%$ in a Belgian study and $8 \%$ in a Polish study, and this is in agreement with our findings [47,50,54]. In conclusion, the increasing antimicrobial resistance rate in hospitals and the possible dissemination of resistant bacteria in the inanimate surfaces or the hands of health professionals and patients, reinforce the need for knowledge and control of the sources of pathogens in the hospital environment. The evaluation of the environmental role in the acquisition of healthcare associated infections is needed to collaborate with infection control committees. The establishment of a control system is also required in hospitals for the reduction of the length of stay, costs and morbidmortality. Such a surveillance system should continuously report the prevalence of microorganisms and their resistance pattern to hospital wards; this information will be used in defining policies for control of hospital environments, and building awareness about the diminished efficacy of antibiotics with the wide-scale use, especially in Moroccan hospitals where antimicrobial prescription is sometimes inappropriate. Thus, more attention must be given to the implementation of effective approaches to optimize antimicrobial use.

\section{References}

1. Muto CA, Sistrom MG, Farr BM (2000) Hand hygiene rates unaffected by installation of dispensers of a rapidly acting hand antiseptic. Am J Infect Control 28: 273-276.

2. Lemmen SW, Häfner H, Zolldann D, Stanzel S, Lütticken R (2004) Distribution of multi-resistant Gram-negative versus Gram-positive bacteria in the hospital inanimate environment. J Hosp Infect 56: 191-197.

3. Sexton T, Clark P, O'Neill E, Dillane T, Humphreys H (2006) Environmental reservoirs of methicillin-resistant staphylococcus aureus in isolation rooms: correlation with patient isolates and implications for hospital hygiene. J Hosp Infect 62: 187-194.

4. Bonten MJ, Hayden MK, Nathan C, van Voorhis J, Matushek M, et al. (1996) Epidemiology of colonisation of patients and environment with vancomycinresistant enterococci. Lancet 348: 1615-1619.

5. Boyce JM, Potter-Bynoe G, Chenevert C, King T (1997) Environmental contamination due to methicillin-resistant Staphylococcus aureus: possible infection control implications. Infect Control Hosp Epidemiol 18: 622-627.

6. Martinez JA, Ruthazer R, Hansjosten K, Barefoot L, Snydman DR (2003) Role of environmental contamination as a risk factor for acquisition of vancomycin resistant enterococci in patients treated in a medical intensive care unit. Arch Intern Med 163: 1905-1912.

7. French GL, Otter JA, Shannon KP, Adams NM, Watling D, et al. (2004) Tackling contamination of the hospital environment by methicillin-resistant Staphylococcus aureus (MRSA): a comparison between conventional terminal cleaning and hydrogen peroxide vapour decontamination. J Hosp Infect 57: 31-37.

8. Curtis LT (2008) Prevention of hospital-acquired infections: review of nonpharmacological interventions. J Hosp Infect 69: 204-219.

9. Goldmann DA, Huskins WC (1997) Control of nosocomial antimicrobialresistant bacteria: a strategic priority for hospitals worldwide. Clin Infect Dis 24 Suppl 1: S139-145.

10. Karchmer TB, Durbin LJ, Simonton BM, Farr BM (2002) Cost-effectiveness of active surveillance cultures and contact/droplet precautions for control of methicillin-resistant Staphylococcus aureus. J Hosp Infect 51: 126-132.

11. Chetchotisakd P, Phelps CL, Hartstein Al (1994) Assessment of bacterial crosstransmission as a cause of infections in patients in intensive care units. Clin Infect Dis 18: 929-937.

12. Weist K, Pollege K, Schulz I, Rüden H, Gastmeier P (2002) How many nosocomial infections are associated with cross-transmission? A prospective cohort study in a surgical intensive care unit. Infect Control Hosp Epidemiol 23: $127-132$.

13. Garner JS (1996) Guideline for isolation precautions in hospitals. The Hospital 
Citation: Bakkali MEL, Hmid K, Kari KE, Zouhdi M, Mzibri MEL, et al. (2015) Characterization of Bacterial Strains and their Resistance Status in Hospital Environment. J Trop Dis 4: 180. doi:10.4172/2329-891X.1000180

Page 6 of 6

Infection Control Practices Advisory Committee. Infect Control Hosp Epidemiol 17: 53-80.

14. Recommendations of the Hospital Infection Control Practices Advisory Committee HICPAC (1995) Recommendations for preventing the spread of vancomycin resistance. MMWR Recomm Rep 44: 11-13.

15. Arnold MS, Dempsey JM, Fishman M, Mc Auley PJ, Tibert C, et al. (2002) The best hospital practices for controlling methicillin-resistant Staphylococcus aureus: on the cutting edge. Infect Control Hosp Epidemiol 23: 69-76

16. Danforth D, Nicolle LE, Hume K, Alfieri N, Sims H (1987) Nosocomial infections on nursing units with floors cleaned with a disinfectant compared with detergent. J Hosp Infect 10: 229-235.

17. Maki DG, Alvarado CJ, Hassemer CA, Zilz MA (1982) Relation of the inanimate hospital environment to endemic nosocomial infection. N Engl J Med 307: 1562-1566.

18. Huang SS, Datta R, Platt R (2006) Risk of acquiring antibiotic-resistant bacteria from prior room occupants. Arch Intern Med 166: 1945-1951.

19. Frost $M$ and Sullivan K (2010) Hospital-aquired infections-Trends across Europe. M56E-54.

20. Gaynes PR, Horan CT (1997) Surveillance of 15 nosocomial infections In: Mayhall C. eds. Hospital Epidemiology and Infection Control, 2nd edition. Philadelphia: Lippincott, Williams and Wilkins p 1297-1307.

21. Baron J, Finglod S (1996) Methods for identification of ethiologic agents of infections diseases. In : St. Louis, USA, editors. Baliy \& Scott's diagnostic microbiology, 10th edition. Mosby: Inc p 327-529.

22. National Committee for Clinical Laboratory Standard Institute (2003) Performance Standards for Antimicrobial Susceptibility Testing. 12th Information Supplement, M100-S14. NCCLS, Wayne, PA.

23. National Committee for Clinical and Laboratory Standard Institute (2005) Performance standards for antimicrobial disk susceptibility tests. Documents M100 S15. NCCLS. Wayne, PA, USA.

24. Dubberke ER, Reske KA, Noble-Wang J, Thompson A, Killgore G, et al. (2007) Prevalence of clostridium difficile environmental contamination and strain variability in multiple health care facilities. Am J Infect Control 35: 315-318.

25. Duckro AN, Blom DW, Lyle EA, Weinstein RA, Hayden MK (2005) Transfer of vancomycin-resistant enterococci via health care worker hands. Arch Intern Med 165: 302-307.

26. Bhalla A, Pultz NJ, Gries DM, Ray AJ, Eckstein EC, et al. (2004) Acquisition of nosocomial pathogens on hands after contact with environmental surfaces near hospitalised patients. Infect Control Hosp Epidemiol 25: 164-167.

27. Larson E (1999) Skin hygiene and infection prevention: more of the same or different approaches? Clin Infect Dis 29: 1287-1294.

28. Rosenthal VD, Guzman S, Safdar N (2005) Reduction in nosocomial infection with improved hand hygiene in intensive care units of a tertiary care hospital in Argentina. Am J Infect Control 33: 392-397.

29. Rupp ME, Fitzgerald T, Puumala S, Anderson JR, Craig R, et al. (2008) Prospective, controlled, cross-over trial of alcohol-based hand gel in critical care units . Infect Control Hosp Epidemiol 29: 8-15.

30. Noskin GA, Stosor V, Cooper I, Peterson LR (1995) Recovery of vancomycinresistant enterococci on fingertips and environmental surfaces. Infect Control Hosp Epidemiol 16: 577-581.

31. Kampf G, Kramer A (2004) Epidemiologic background of hand hygiene and evaluation of the most important agents for scrubs and rubs. Clin Microbiol Rev 17: 863-893, table of contents.

32. Gastmeier P, Schwab F, Bärwolff S, Rüden H, Grundmann H (2006) Correlation between the genetic diversity of nosocomial pathogens and their survival time in intensive care units. J Hosp Infect 62: 181-186.

33. Wendt C, Dietze B, Dietz E, Rüden H (1997) Survival of Acinetobacter baumannii on dry surfaces. J Clin Microbiol 35: 1394-1397.

34. Hirai $Y$ (1991) Survival of bacteria under dry conditions; from a viewpoint of nosocomial infection. J Hosp Infect 19: 191-200.
35. Beard-Pegler MA, Stubbs E, Vickery AM (1988) Observations on the resistance to drying of staphylococcal strains. J Med Microbiol 26: 251-255.

36. Weber DJ, Rutala WA (1997) Role of environmental contamination in the transmission of vancomycin-resistant enterococci. Infect Control Hosp Epidemiol 18: 306-309.

37. Griffiths C, Lamagni TL, Crowcroft NS, Duckworth G, Rooney C (2004) Trends in MRSA in England and Wales: analysis of morbidity and mortality data for 1993-2002. Health Stat Q : 15-22.

38. Centers of Disease Control and Prevention (2002) Campaign to prevent antimicrobial resistance in healthcare settings: slide set: 12 steps to prevent antimicrobial resistance among hospitalized adults.

39. Zaidi AK, Huskins WC, Thaver D, Bhutta ZA, Abbas Z, et al. (2005) Hospitalacquired neonatal infections in developing countries. Lancet 365: 1175-1188.

40. Vránková J, Bendová E, Königová R, Broz L (1998) Bacteriological monitoring in the Prague Burns Center. Acta Chir Plast 40: 105-108.

41. Ransjö U, Good Z, Jalakas K, Kühn I, Siggelkow I, et al. (1992) An outbreak of Klebsiella oxytoca septicemias associated with the use of invasive blood pressure monitoring equipment. Acta Anaesthesiol Scand 36: 289-291.

42. Deplano A, Denis O, Poirel L, Hocquet D, Nonhoff C, et al. (2005) Molecular characterization of an epidemic clone of panantibiotic-resistant Pseudomonas aeruginosa. J Clin Microbiol 43: 1198-1204.

43. Enoch DA, Summers C, Brown NM, Moore L, Gillham MI, et al. (2008) Investigation and management of an outbreak of multidrug-carbapenemresistant Acinetobacter baumannii in Cambridge, UK. J Hosp Infect 70: 109118.

44. Kayabas U, Bayraktar M, Otlu B, Ugras M, Ersoy Y, et al (2008) An outbreak of Pseudomonas aeruginosa because of inadequate disinfection procedures in a urology unite: A pulsedfield gel electrophoresis-based epidemiologic study. Am J Infect Control 36: 33-38.

45. Gaynes R, Edwards JR; National Nosocomial Infections Surveillance System (2005) Overview of nosocomial infections caused by gram-negative bacilli. Clin Infect Dis 41: 848-854.

46. Quinn JP (1998) Clinical problems posed by multiresistant nonfermenting gram-negative pathogens. Clin Infect Dis 27 Suppl 1: S117-124.

47. Hadadi A, Rasoulinejad M, Maleki Z, Yonesian M, Shirani A, et al. (2008) Antimicrobial resistance pattern of Gram-negative bacilli of nosocomial origin at 2 university hospitals in Iran. Diagn Microbiol Infect Dis 60: 301-305.

48. Al-Lawati AM, Crouch ND, Elhag KM (2000) Antibiotic consumption and development of resistance among gram-negative bacilli in intensive care units in Oman. Ann Saudi Med 20: 324-327.

49. Bayram A, Balci I (2006) Patterns of antimicrobial resistance in a surgica intensive care unit of a university hospital in Turkey. BMC Infect Dis 6: 155.

50. Glupczynski Y, Delmée M, Goossens H, Struelens M; Belgian Multicenter ICU Study Group (2001) Distribution and prevalence of antimicrobial resistance among gram-negative isolates in intensive care units (ICU) in Belgian hospitals between 1996 and 1999. Acta Clin Belg 56: 297-306.

51. Karlowsky JA, Draghi DC, Jones ME, Thornsberry C, Friedland IR, Sahm DF (2003) Surveillance for antimicrobial susceptibility among clinical isolates of Pseudomonas aeruginosa and Acinetobacter baumannii from hospitalized patients in the United States, 1998 to 2001. Antimicrob Agents Chemother 47 1681-1688.

52. Rodríguez CH, Juárez J, de Mier C, Pugliese L, Blanco G et al. (2003) [Bacterial resistance to antibiotics in gram-negative rods isolated from intensive care units. Comparative analysis between two periods (1998 and 2001)] Medicina (B Aires) 63: 21-27.

53. Mendes C, Oplustil C, Sakagami E, Turner P, Kiffer C; MYSTIC Brazil Group (2005) Antimicrobial susceptibility in intensive care units: MYSTIC Program Brazil 2002. Braz J Infect Dis 9: 44-51.

54. Patzer J, Dzierzanowska D, Turner P (2002) Susceptibility patterns of Gramnegative bacteria from a Polish intensive care unit, 1997-2000. Int J Antimicrob Agents 19: 431-434. 